\title{
Legal Responsibilities of the Boards of Directors of Persero State-Owned Enterprises Agency towards Losses Conducted by Directors' Loss
}

\author{
Susanto ${ }^{1 *}$ \\ 1Pamulang University South Tangerang City, Banten Province, Indonesia
}

\begin{abstract}
In conducting business, especially BUMN (Persero) faces various business risks both from the internal BUMN (Persero) itself and from the external. Losses from internal state-owned enterprises (Persero) can be caused by miss management or fraudulent directors. When the BUMN (Persero) experiences losses caused by fraudulent directors, problems arise when connected with BUMN (Persero) capital that comes from State assets (APBN) that have been separated.
\end{abstract}

\section{Introduction and Literature review}

\subsection{State-Owned Enterprises (BUMN)}

State Owned Enterprises are legal entities that are partially or wholly owned by the State, which have the purpose of providing public services and running businesses or businesses to seek profit. In an effort to seek profits, BUMNs, especially BUMN (Persero), use all their resources, both human resources and funding sources. Over time and the development of the world economy that demands BUMN and BUMD to be able to compete with private companies both domestically and internationally. Therefore another challenge of stateowned companies is how companies can become the driving force of economic activities and enhancing people's welfare.

As for the functions and roles of BUMN, namely:

1) To contribute to the national economy and state cash receipts;

2) Chase and seek profit

3) Fulfillment of the lives of many people;

4) Pioneering other business activities;

5) Providing assistance and protection to small businesses.[1]

${ }^{*}$ Corresponding author: susantogss@yahoo.com 


\subsection{The theory of cheating}

ACFE describes fraud in the form of a fraud tree. This Fraud tree is usually presented in the form of a chart. Fraud tree has three main branches, namely corruption, asset misappropriation, and fraudulent statements. The fraud triangle theory can be seen in the following figure:

PERCEIVED

OPPORTUNITY

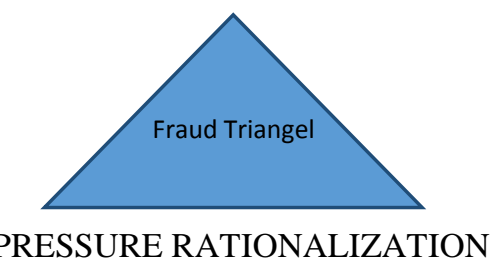

Picture: Fraud Triangle Theory[2]

One of the theoretical explanations for acts of fraud was delivered by Cressey (1953). According to him, someone can commit fraud if it is based on three things, namely opportunity, pressure or incentive (pressure or incentive) and rationalization. The three support each other and form a pillar of fraud which is called the fraud triangle.[3]

The first element of the cheating triangle is pressure. Pressure can be caused by various things including financial and non-financial pressures. Financial factors arise because of the desire to have a material lifestyle. While non-financial factors can encourage someone to commit fraud, which is an action to cover a poor performance. Besides that, the greedy nature of human beings can put pressure internally, thus encouraging someone to commit fraud.[3]

The second cheating factor is opportunity. The opening of this opportunity is because the perpetrator believes that their activities will not be detected. Even if someone's action is known, then no serious action will be taken. This opportunity occurs usually related to the environment where fraud is possible. Weak internal control system, inadequate supervision management and unclear procedures contribute to opening up opportunities for fraud.[3]

The third element in the act of cheating is rationalization. This is a justification for the actions taken. The perpetrators of fraud usually seek various reasons rationally to justify their actions. Vona, Leonard W stated that in measuring three elements of a fraud triangle it is not as simple as measuring a person's temperature.[3]

\subsection{Legal Responsibility Concept}

According to Abdulkadir Muhammad[4] the theory of responsibility in tort liability is divided into several theories, namely:

1) Responsibility due to intentional violation of the law (intertional tort liability), the defendant must have committed an act in such a way as to harm the plaintiff or know that what the defendant will do will result in a loss.

2) Responsibility due to law violations committed due to negligence (negligence tort lilability), is based on a concept of fault related to moral and legal intermingling.

3) Absolute responsibility as a result of unlawful conduct without stirck liability, based on his actions either intentionally or unintentionally, meaning that even if it is not his fault he is still responsible for losses arising from his actions.

In order to be held legally liable, there must be a causality relationship between the actions committed and the losses that occur and there is an element of error. Errors are considered to exist if they fulfill one of the 3 (three) conditions as follows: 
1) There is an element of intent;

2) There is an element of negligence (negligence, culpa);

3) There are no justification reasons or forgiveness reasons.

Errors include two senses, namely mistakes in the broadest sense (there is negligence and intentionality) and errors in the narrow sense (only in the form of intentions). The inclusion of the error conditions in Article 1365 of the Civil Code, the legislators wished to emphasize that the perpetrators of unlawful acts were only responsible for the losses incurred if the act could be blamed on him. Vollmar states that lawmakers apply the term schuld (error) in several meanings, namely:

1) The perpetrator's responsibility for the act and for the loss caused by the act;

2) Ignorance as opposed to deliberate;

3) Nature against the law.

In terms of its severity, the degree of error of perpetrators of unlawful acts, then it is compared with unlawful acts committed with negligence, then an unlawful act committed with an element of intentional error is higher. If someone who intentionally harms another person (either for his own benefit or not), it means that he has committed an act that violates the law in a very serious sense than doing it merely by negligence. The act of breaking the law or onregtmatigedaad is the concept of private law accountability. The form of responsibility in civil law is payment of compensation. Onregtmatigedaad is regulated in Article $1365 \mathrm{BW}$ that, "every act that violates the law and brings harm to others, requires that people incur losses because of their mistakes to compensate". In this case an error or omission must result in the loss of another party. Losses in the economic sense while the punishment for the guilty is paying compensation.

\section{Methodology}

In this study researchers used a normative approach with a qualitative research model. The data used are secondary data consisting of: primary legal materials namely the provisions of law and legislation related to the object of the research, as well as secondary legal materials consisting of doctrine and references of opinion from experts who are expected to strengthen the deepening of the object of research. Data processing is done by analyzing all the data that have relevance to the object of research. Thus, it is expected to provide a very substantive and objective research results.

\section{Discussion}

\subsection{Business Judgment Rules}

The cause of BUMN's losses is of course not only by corrupt behavior, but also can be by miss management or pure business loss. Therefore, it should be necessary to look at other considerations, namely the existence of the doctrine of business judgment rules by the directors and the board of commissioners as stipulated in Article 97 paragraph (5) and Article 107 paragraph (5) of Law Number 40 of 2007 which concern on Limited Liability Companies (PT ) "Business Judgment Rule" is one of the doctrines in corporate law which stipulates that the directors of a company are not responsible for the losses, arising from an act of decision making, if the actions of the directors are based on good faith and caution. With this principle, directors get protection, so there is no need to obtain justification from shareholders or the court for their decisions in managing the company. According to Remi Syahdeni, based on the Business Judgment Rules, the business considerations of the board directors' members cannot be challenged or contested or rejected by the court or 
shareholders. The board of directors' members cannot be liable for the consequences arising from having taken a business consideration by the board of directors' member in question even if the consideration is wrong, except in certain cases.

The theory of business judgment rule has been applied in Indonesian law. In Article 97 paragraph (5) of Law No. 40 of 2007 concerning to the Limited Liability Companies stated that the Board of Directors cannot be held personally liable for the loss of the company as stated in paragraph (3). The basic principle of not being asked for personal accountability of the Board of Directors is the reasonable choice of business directors' legal actions. Therefore, the elements of the Board of Directors 'prudence must be proven and the Directors' bad faith is the basis for the claim of liability for the loss of the company.

In the law of the company known as the Business Judgment Rule Doctrine, this doctrine originated in the United States based on the common law legal system, where the main legal source for the United States is jurisprudence. The Business Judgment Rule concept has been implemented 170 years ago in the United States and has played a very important role in the company and in business cases. In general, this doctrine is a doctrine that provides protection for directors against business decisions taken.

Business Judgment The rule is the legal doctrine that the corporation's officers and directors can be liable for damages to stockholders for a business decision that is harmful to the corporation so long as the decision is within the officers 'or directors' discretionary power and was made on an informed basis, in good faith without any direct conflict of interest, and in the honest and reasonable belief that it is in the corporation's best interest.[5]

The Business Judgment Rule is based on several reasons, namely:

1) The Director is only responsible for managing the company, not for the company's profits or the company's losses, and is not responsible for third parties.

2) The Director is not a guarantor that the company he manages will not experience a loss during the company's business activities.

3) The Board of Directors in making business decisions has made reasonable and reasonable considerations where in the case of others being in the same situation will take the same decision.

4) The Board of Directors in making business decisions based on good faith.

5) The Board of Directors has managed the company as well as possible as the real owner and with full responsibility.

6) The Board of Directors in making business decisions is entirely for the benefit of the company and based on the belief that the decisions taken are the best for the company.

Based on the reasons mentioned above, business decisions taken by the board of directors are considered the best decisions for the company. The best decision for the company is not necessarily a decision that does not bring harm to the company, but in running the business many factors influence, therefore it can be possible for a business decision that is best for the loss company that arises is the best decision if the decision is not taken by the directors or another decision is taken, the company will suffer a greater loss from the decision taken.

An understanding of the Business Judgment Rule doctrine can be understood based on the principle of the Presumption of Innocence which is also known as the principle of "presumption of innocence", wherein this principle is considered innocent until a party can prove that he is guilty and the court issues a permanent legal force stating that the person is guilty, as is the board of directors, is considered innocent and is not personally liable for losses caused by business decisions taken by the board of directors until there are parties who can prove that the company's loss is a mistake and negligence of the board of directors in making decisions, this must also followed by filing a lawsuit in court. The element of an 
error or omission must be proven as the cause of the loss of the decision of the board of directors.

The Business Judgment Rule protects directors from personal liability for losses to the company only on business decisions that clearly fulfill the fiduciary duty and the actions and actions of the directors are included in intra vires, the actions of the ultra vires directors cannot be protected by the Business Judgment Rule doctrine.

The Company is not responsible for more than the actions carried out in accordance with the goals and objectives of the company, therefore the actions and actions taken by the directors that are not in accordance with the goals and objectives of the company listed in the articles of association are the personal responsibility of the board of directors and are not the responsibility of the company In addition, the ultra vires provision is not only about the directors' actions for the interests of the company that are not in line with the company's intentions and objectives, but also includes the actions of directors that exceed the authority granted by the company to the directors.

Although the board of directors conducts the company legally for the benefit of the company, it does not mean that the board of directors can carry out management actions for purposes that are not in accordance with the goals and objectives of the company, especially if the purpose is for the personal benefit of the directors.

If in this case there is a loss due to the ultra vires action taken by the board of directors in managing the company, the board of directors must take full personal responsibility for the ultra vires action, but if the ultra vires action benefits the company, the profit belongs to the company, in addition if the directors take advantage by using the name of the company, the assets of the company, and for reasons of the company's interests, the board of directors is considered to violate fiduciary duty.

\subsection{Legal Liability Due to Cheat}

As a consequence of the accountability of state financial management, both in the State Finance Law, the State Treasury Law, as well as Law Number 15 of 2004 concerning the Examination of the Management and Responsibility of State Finance, regulates criminal provisions, administrative sanctions and compensation applicable to ministers or leaders institutions and leaders of organizational units of State Ministries or institutions that have proven to deviate from policies or activities that have been stipulated in the law. The same thing applies to treasurers who are in charge of managing money or goods that have been responsible for violating the law which has caused financial losses to the state. In addition, the understanding of a person is not only a treasurer, including civil servants not treasurers and other officials in charge of managing state finances.

Referring to the provisions of Article 22 paragraph (5) of the Law on Management and State Financial Responsibility Examination shows that Persero Directors who violate the law or neglect their obligations related to State finances, either directly or indirectly that are detrimental to State finances, can be subject to sanctions in accordance with the BPK provisions . On the other hand this arrangement confirms that the BPK has the authority to examine the finances of all Persero.

The inclusion of the provision for imposing compensation on the management or manager of BUMN Persero in the provisions of the articles governing the imposition of compensation against the treasurer shows that in the end the provisions or procedures for the settlement of state losses carried out by BPK against the treasurer carry legal implications that the settlement of state losses imposed the treasurer also applies to SOE Persero managers.

The management of a State-Owned Enterprise in detail is not explained in the legislation, but in the Elucidation of Article 10 of Law Number 15 of 2006 concerning the 
State Audit Board, it is explained that the "manager" is defined as an employee of a State or regional company and other institutions or agencies. Thus, it can be interpreted that the party referred to as the "manager" of a state-owned enterprise is the board of directors, commissioners, and all employees who run daily operational management of the company.

The provision of compensation for the state manager stipulated by the BPK is very useful in efforts to recover or recover state losses. Although all this time the rules regarding the procedure for resolving state losses to SOEs have no real regulations in the form of laws and regulations from the BPK itself, at least the provisions regarding the settlement of state losses as stipulated in the State Finance Law, State Treasury Law and Examination Law State Financial Management and Responsibility can be applied to state losses to SOEs associated with PSO implementation. Thus, there is no legal vacuum if faced with a case of state losses to BUMN Persero.

\section{Conclusion and Suggestions}

\subsection{Conclusion}

The concept of legal accountability of the directors of BUMN (Persero) against losses caused by fraudulent directors of BUMN (Persero), the directors are prosecuted in the general court and not a criminal act of corruption, because BUMN (Persero) is a private legal entity that is subject to the concept of Business Judgment Rule. Civil court directors who commit fraud [are illegal actions] can be sued in a civil manner with compensation claims for illegal actions.

\subsection{Suggestions}

Firm rules are needed to formulate the BUMN. BUMN is a private legal entity and losses on BUMN. BUMN are not state losses but are the responsibility of BUMN Persero itself. This can be done by eliminating the mention of BUMN in Law Number 17 of 2003 concerning State Finance; Law Number 1 of 2004 concerning State Treasury and Law Number 31 of 1999 concerning Eradication of Corruption Crimes as amended by Act Number 20 of 2001 concerning Amendments to Law Number 31 of 1999 concerning Eradication of Acts Corruption Crime. This is a legal consequence of the application of the principle of civil law in the case of capital deposits in a legal entity, so any material property or wealth deposited into a limited liability company and or public company is a legal event that is always classified into a transaction between the founder or holder shares with the Company or Perum itself. Furthermore, Article 3 paragraph (1) of Law Number 40 of 2007 concerning on Limited Liability Companies stipulates that the Company's Shareholders are not personally liable for the commitments made on behalf of the company and are not responsible for the loss of the company over the value of the shares taken.

\section{References}

1. Badan Pusat Statistik, Statistik Keuangan Badan Usaha Milik Negara dan Badan Usaha Milik Daerah 2013, Jakarta, (2014)

2. T. M. Tuanakotta, AkuntansiForensik dan Audit Investigatif Edisi 2 (Salemba Empat. Jakarta, 2010).

3. Vona, Leonard W. Fraud Risk Assessment Building A Fraud Audit Program. (Wiley \& Sons, Inc, New Jersey, 2008).

4. A. Muhammad, Hukum Perusahaan Indonesia, (Citra Aditya Bakti, Indonesia, 2010). 
5. S. E. Wild, Webster's New World Law Dictionary, (Wiley Publishing, Inc, Canada, 2006). 